\title{
Breeding Endangered Species
}

The 3rd World Conference on Breeding Endangered Species in Captivity, covering both self-sustaining captive populations and re-introductions into the wild, was held in San Diego, California, from November 12 to 16, 1979. It was co-sponsored by the Fauna Preservation Society, which initiated the conferences and had co-sponsored the earlier ones at Jersey Zoo in 1972 and London Zoo in 1976, and by the Zoological Society of San Diego, which made all the very efficient local arrangements.

It was generally agreed that this was the best and most realistic of the three conferences on breeding endangered species in captivity. In the discussion at the end, led by Dr William Conway of the New York Zoological Society, the zoo representatives faced up to the possibility that by the end of the century, if habitat destruction cannot be checked, there may be many animals for which the only safeguard against extinction is captive breeding.

Among the highlights of the meeting was Gerald Durrell's report on the remarkable successes the Jersey Wildlife Preservation Trust has had with breeding the endangered Mascarene endemics, notably the pink pigeon Nesoenas mayeri (six young raised), Meller's duck Anas melleri (924 young raised) and the Rodrigues fruit bat Pteropus rodricensis (more than 10 young raised). Counterpart breeding programmes in Mauritius have had similar successes, including the rearing of a young Mauritius kestrel $F$ alco punctatus. General Avram Yoffe gave a stimulating account of his successes, as Chairman of the Israel Nature Reserves Authority, in breeding such endangered species as onager, Somali wild ass, addax and scimitar-horned oryx, at Hai-Bar in the Negev. With some relish he reported that four Persian fallow deer had been received from Iran, to join two pairs from Kronberg Zoo, West Germany, only days before all traffic in and out of Iran was brought to a halt. Major Iain Grahame described the work of the World Pheasant Association in reintroducing stocks of captive-bred endangered pheasants, and Ray Erickson discussed the endangered species breeding programme of the US Fish and Wildlife Service at Patuxent, Maryland.

All the papers at the San Diego conference will be reproduced in the 1980 International Zoo Yearbook to be published in the summer of 1980. Plans for the next conference are already being laid. The FPS Council hopes that it will be able to arrange this in 1984 .

RSRF

\section{IUCN in the Eighties}

IUCN has celebrated the new decade first by moving its offices and second by producing a new three-year programme. The new offices, shared with WWF, are at Gland, halfway along the lakeshore towards Geneva from Morges, where IUCN had been ever since it moved from Brussels in the early 1960s. The Conservation Programme for Sustainable Development 1980-1982 is the first-fruits of a process that had been going on ever since the last General Assembly at Ashkhabad in September 1978. It occupies nearly 150 pages of extensively tabulated material, and reveals for the first time the remarkable breadth of activity of IUCN's six commissions. The Survival Service 
Commission, with which FPS is most closely connected, has had such a programme for several years, but now that the other commissions present their programmes in an orderly way, IUCN's activity does not seem to be quite so biased in the direction of species protection as it was before Ashkhabad, when other commissions were less active. The development of the Red Data Books features high among the SSC's priorities; so does the work of the TRAFFIC Group, which is closely associated with FPS. Threatened plants are picked out as a priority group, and so are primates, marine mammals, cats, elephants, rhinos, desert ungulates, threatened birds, marine turtles, crocodiles and all Madagascar fauna and flora. The eight other programme areas (to use the jargon of the computer age) of the IUCN Programme include development planning, education, ecosystems and protected areas, i.e. national parks and nature reserves.

\section{Bahrain to the Rescue}

Only 14 of the 52 South African animals stranded for six days at Rome Airport last September survived, and their survival was entirely thanks to the rescue operation mounted by Bahrain's Al Areen Wildlife Park and Reserve. The plane had been refused clearance to continue its journey from South Africa to Naples because of 'inadequate documentation', and more than half the animals died in the plane in the days it stayed at Rome airport. Al Areen Wildlife Park agreed to take the 23 survivors as a humanitarian operation, but nine more died as a result of their appalling experiences. The 14 survivors were seven Chapman's zebra, two bushbuck, one blesbok, three springbok, and one mountain reedbuck. The Park's Deputy Director, Faisal A. Izzeddin, gives some idea in his report of the conditions in the plane when it arrived:

'The stench of ammonia from the urine in the aircraft had caused respiratory difficulties in the animals over the past six days resulting in the death of many of them. The crew and their assistants had blood-shot eyes and were barely able to talk due to breathing the ammonia throughout the flight.'

\section{Persian Fallow Deer}

In Oryx June 1979, page 65, we quoted figures from Iran for Persian fallow deer Dama dama mesopotamica. Mrs Norma Chapman writes: 'The figures in the note for wild deer in Iran are very optimistic. I visited Iran in December 1977 to see these deer and their habitat, and since then I have again seen and corresponded with Sam Hess, the biologist studying the deer who early last year had to flee back to the USA.

'At Dasht-e-Naz the deer are enclosed and in December 1977 there were indeed 50-55 animals present. Of the three deer which were flown to Asht Island in Lake Rezaiyeh, one female was found dead in August 1978. In the wild in SW Iran the situation was poor. None was believed to survive at Karkheh. At Dez a new road and railway were being built across the refuge, destroying the habitat for a width of about $100 \mathrm{~m}$. The pressure on the habitat from domestic species, including sheep, goats, water buffaloes and camels, was severe. In May 1978 not more than 25 Persian fallow were thought to survive there. Before the troubles of a year ago, there were plans to fence completely the Dez refuge to keep out the domestic stock and the woodcutters. 
Plans were also afoot to purchase land in SW Iran within the Arjan National Park where some deer from Dasht-e-Naz could be released eventually. Undoubtedly such plans will have been abandoned now.

'The most recently published reference to Persian fallow that I know of is C.C. Mueller, 1979, Der mesopomatische Damhirsch-Geschichte und Geschichten.Zeitschrift des Kölner Zoo, 21, 127-134.'

\section{Phyllis Barclay-Smith CBE}

Phyllis Barclay-Smith, who died on January 2, for many years personified international bird protection. She had an exceptionally long career in this field, from 1924, when she became Assistant Secretary of the Royal Society for the Protection of Birds, until 1978, when she retired from the Secretaryship of the International Council for Bird Preservation, which she had held since 1946. Even after her nominal retirement she was continuing to hold the fort until her successor could take up his post in April 1980. In between she was Hon. Secretary of the British Ornithologists' Union from 1945 to 1951 and Editor of the Avicultural Magazine for 34 years up to 1973. She also ran the Advisory Committee on Oil Pollution of the Sea for many years. For her sterling efforts she received no fewer than five gold medals and other honours, including a CBE in 1971. She was a splendid example of the amateur who is more professional than the professionals, a breed which is in as much danger of extinction as the bird species she fought to save.

\section{Joy Adamson}

Joy Adamson, killed at her camp in the bush in Kenya on January 4, had a meteoric ascent in the conservation world when the first of her Elsa lion books, Born Free, was published in 1960 . She showed brilliantly what can be done in the micro-conservation field by personal relationships with individual wild animals, recalling the devotion and dedication of Len Howard in a quite different field. When her Elsa books hit the jackpot, she made over their proceeds to a charitable fund, the Elsa Fund, which has supported many important East African conservation causes and made many projects possible. She was thus an important strand in the wildlife conservation movement in Africa in the latter part of the 20th century, and her influence will last as long as her books and the Fund.

Dr Paul foslin writes: Although she will always be remembered more for her story of Elsa, in the scientific community Joy's most significant accomplishment was with Pippa, a tame cheetah. For several hundred years man has attempted to reproduce captive-reared cheetahs without notable success . . . What Joy did was to take Pippa into the wild and prove that, by giving her adequate training and protecting her from man only, she could survive, mate in the wild and give birth to four healthy cubs. They in turn grew, learned to hunt, passed through the rigours of puberty, found mates and had young of their own. Joy told their story in The Spotted Sphinx and Pippa's Challenge. . . It was because of her love for her animals that Joy had the strength to persevere under the all-too-frustrating conditions that working on big cats entails. I know of few scientists who, under similar circumstances, would be willing to follow around an expanding family of cheetahs for three generations. 